JKEP

Vol 4, No 1, Mei 2019

ISSN: 2354-6042 (Print)

ISSN : 2354-6050 $\underline{\text { (Online) }}$

\title{
Stigma Remaja terhadap ODHA Studi terhadap pelajar SMA di wilayah Jakarta Timur
}

\author{
Suhana Haeriyanto, Ni Luh Putu Ekarini, Dewi Lusiani \\ Jurusan Keperawatan Poltekkes Kemenkes Jakarta III \\ Email: haerihaeriyanto@gmail.com
}

\author{
Artikel history \\ Dikirim, Feb 17 $7^{\text {th }}, 2019$ \\ Ditinjau, April 15 $5^{\text {th }}, 2019$ \\ Diterima, April 26 ${ }^{\text {th }}, 2019$
}

\begin{abstract}
Stigma and discrimination against people with HIV/AIDS (PLWHA) is one of the obstacles in controlling the disease. Stigma and discrimination are carried out by ordinary people, including high school students who do not have sufficient knowledge about HIV / AIDS and a lack of attitudes towards disease recognition programs. The research aims to prove that knowledge can influence high school students in behaving against ODHA, and stima. By using a quasi-experimental design (pretest-posttest control group design) the study was conducted on 88 samples selected using a combination of randomized sampling to determine selected schools and non-randomized consecutive sampling to determine the selected sample units and determine the intervention group and control group. The results showed that there were differences in the average stigma score between the pretest and posttest in the intervention group ( $p=<0.005)$, so it could be concluded that knowledge was proven to have an effect on the stigma of students towards PLWHA.
\end{abstract}

Keywords: Stigma; knowledge; attitude.

\begin{abstract}
ABSTRAK
Stigma dan diskriminasi terhadap penderita HIV/AIDS (ODHA) merupakan salah satu kendala dalam pengendalian penyakit tersebut. Stigma dan diskriminasi dilakukan oleh masyarakat awam, termasuk siswa SMA yang tidak mempunyai pengetahuan yang cukup tentang penyakit HIV/AIDS dan sikap yang kurang terhadap program pengenalian pernyakit. Penelitian bertujuan membuktikan bahwa pegetahuan dapat mempengaruhi siswa SMA dalam bersikap terhaap ODHA, serta melakukan stima. Dengan menggunakan desain kuasi eksperimental (pretest-postesst control group design) penelitian dilakukan terhadap 88 orang sample yang dipilih menggunakan kombinasi Randomized Sampling untuk penentuan Sekolah terpilih dan Non Randomized Consecutive Sampling untuk menentukan unit sample terpilih dan menentukan kelompok intervensi dan kelompok kontrol. Hasil penelitian menunjukan terdapat perbedaan rata-rata skor stigma antara pretest dengan posttest pada kelompok inervensi $(\mathrm{p}=<0.005)$, sehingga dapat disimpulkan
\end{abstract}


bahwa pengetahuan terbukti memberikan pengaruh terhadap stigma pelajar terhadap ODHA.

Kata kunci: Stigma; pengetahuan; sikap.

\section{PENDAHULUAN}

Stigma dan diskriminasi terhadap penderita HIV/AIDS (ODHA) merupakan salah satu kendala dalam pengendalian penyakit HIV/AIDS. Herek \& Capitiano (1999) mengatakan bahwa timbulnya stigma dan diskriminasi terhadap ODHA disebabkan oleh faktor risiko penyakit ini yang terkait dengan perilaku seksual yang menyimpang dan penyalahgunaan narkotika dan obat berbahaya atau narkoba. Wan Yanhai (2009) menyatakan bahwa orang-orang dengan infeksi HIV (HIV positif) menerima perlakuan yang tidak adil (diskriminasi) dan stigma karena penyakit yang dideritanya.

Stigma dan diskriminasi terhadap ODHA dipengaruhi oleh tingkat pengetahuan dan persepsi. Hal ini sesuai dengan hasil penelitian yang dilakukan oleh Mahendra et al (2007) dan oleh Pratikno (2008), yang menunjukkan hasil bahwa adanya stigma dan diskriminasi pada ODHA oleh petugas kesehatan dipengaruhi oleh pengetahuan dan persepsi petugas kesehatan tentang HIV/AIDS. Hasil penelitian lain yang mendukung adalah dari Cock et al (2002) yangmenyatakan bahwa stigma dan diskriminasi terhadap ODHA berhubungan dengan persepsi tentang rasa malu (shame) dan menyalahkan (blame) yang berhubungan dengan penyakit AIDS. Faktor lain yang berpengaruh terhadap stigma dan diskriminasi adalah faktor kepatuhan terhadap agama. Kepatuhan terhadap nilai-nilai agama para petugas kesehatan dan para pemimpin agama mempunyai peran dalam pencegahan dan pengurangan penularan HIV. Hasil penelitian yang dilakukan oleh Diaz di Puerto Rico tahun 2011 menyatakan adanya peran agama dalam membentuk konsep tentang sehat dan sakit serta terkait dengan adanya stigma terhadap penderita HIV/AIDS (Diaz et al, 2011).

Menurut Notoatmodjo (2012), pengetahuan merupakan hasil dari tahu dan ini terjadi setelah orang melakukan penginderaan terhadap suatu objek tertentu. Pengetahuan atau kognitif merupakan domain yang sangat penting untuk terbentuknya tindakan seseorang 
(overt behavior). Selanjutnya Notoatmodjo mengemukakan bahwa pengetahuan yang dicakup dalam domain kognitif mempunyai enam tingkatan, yaitu tahu (Know), paham (comprehension), aplikasi (aplicaion), analisis (analysis), sintesa (synthesis), dan evaluasi (evaluation).

Sikap merupakan reaksi atau respons yang masih tertutup dari seseorang terhadap suatu stimulus atau objek (Notoatmodjo, 2012). Beberapa batasan lain tentang sikap ini dapat dikutipkan seperti berikut: Cardno, 1995 (dalam Notoatmodjo, 2012) mengemukakan definisi sikap yaitu: "Attitude entails an existing predisposition to respond to socisl objects which in interaction with situational and other dispositional variables, guide and direct the overt behavior of the individual".

Definisi tersebut memberi gambaran bahwa manifestasi sikap tidak dapat langsung dilihat, tetapi harus ditafsirkan terlebih dahulu sebagai tingkah laku yang masih tertutup. Sedangkan Newcomb, 1978 (dalam Notoatmodjo, 2012) membatasi sikap secara lebih operasional, yaitu "The state of readiness for motive arousal". Motif tersebut menyebabkan terjadinya tindakan tertentu sehingga dapat dikatakan bahwa sikap adanya kesiapan, kesediaan untuk bertindak dan bukan sebagai pelaksana motif tertentu. Jadi, sikap merupakan kesiapan untuk berreaksi terhadap objek di lingkungan tertentu sebagai suatu penghayatan terhadap objek tersebut.

Menurut Bradley (dalam Paryati, 2012) Pengetahuan tentang HIV/AIDS sangat mempengaruhi bagaimana individu tersebut akan bersikap terhadap penderita HIV/AIDS. Stigma dan diskriminasi terhadap ODHA muncul berkaitan dengan ketidaktahuan tentang mekanisme penularan HIV, perkiraan risiko tertular yang berlebihan melalui kontak biasa dan sikap negatif terhadap kelompok social yang tidak proporsional yang dipengaruhi oleh epidemi HIV/AIDS ini (Herek, 2002). Chase dan Aggleton (2001) mengatakan bahwa salah satu penyebab terjadinya stigma adalah misinformasi mengenai bagaimana HIV ditransmisikan (Chase and Aggleton, 2001).

Menurut Jacoby (dalam Krisanty, 2015) Stigma didefinisikan sebagai suatu 
atribut penghinaan mendalam yang menurunkan seseorang pada keadaan yang kacau dan akhirnya menjadi direndahkan. Ini adalah suatu masalah menetap yang dapat mempengaruhi kesehatan secara global, mengancam psikologis dan kesehatan fisik seseorang. Selanjutnya Krisanty (2015) menjelaskan bahwa hal tersebut dapat mencegah seseorang untuk terus memeriksakan kesehatannya dan mengganggu kemampuan mereka untuk pergi ke institusi kesehatan atau berpartisipasi dalam studi-studi penelitian untuk mencari solusi. Banyak perhatian telah ditekankan pada dilemma menjadi seseorang yang terstigma, termasuk mereka dengan AIDS atau dicurigai menderita AIDS, mereka dengan lepra, dan mereka yang menderita gangguan kesehatan mental. Tetapi stigma melebihi gangguan-gangguan tersebut kepada kondisi-kondisi kesehatan yang tidak lagi terstigma di negara maju tetapi terus memberikan dampak pada negara-negara miskin. Menurut UNAIDS, diskriminasi terhadap penderita HIV digambarkan selalu mengikuti stigma dan merupakan perlakuan yang tidak adil terhadap individu karena status HIV mereka, baik itu status sebenarnya maupun hanya persepsi saja (UNAIDS, 2012).

\section{METODE}

Penelitian menggunakan desaian quasi experimental dengan pendekatan non randomized pretest-posttest control group. Penelitian dilakukan dengan memberikan intervensi berupa pendidikan kesehatan tentang HIV dan AIDS pada kelompok intervensi dan membandingkan hasil dengan kelompok kontrol atau kelompok tanpa intervensi khusus. Penelitian ini dilakukan terhadap siswa SMA diwilayah Jakarta Timur dan melalui simple random diperoleh bahwa SMAN 64 menjadi sekolah terpilih

Metoda pengambilan sampel terdiri atamenggunakan Purposive sampling dengan besar sampel menggunakan formula proporsi pada satu populasi (Lemeshow, Holmer, Klar \& Lwanga, 2002). Dengan menggunakan rumus dari software maka diperoleh jumlah sampel sebesar 40 responden. Sebagai antisipasi drop out, ditambahkan 10\% sehingga total sampel menjadi 44 orang. Sampel dalam penelitian ini terdiri dari dua kelompok, yaitu kelompok eksperimen yang berjumlah 44 orang dan 
kelompok kontrol yang juga berjumlah 44 orang.

Penelitian ini dilakukan pada bulan September - Oktober 2018. Tempat yang akan digunakan adalah SMAN 64 Jakarta Timur. Sedangkan ehical clearance dilakukan oleh Komisi Etik Poltekkes Kemenkes Jakarta III.

Instrumen penelitian yang dipergunakan dalam penelitian adalah kuesioner dengan teknik pengumpulan data angket. Sedangkan analisis data terdiri atas analisis univariat berupa deskripsi setiap 1. Karakteristik Responden variabel, dan analisis bivariat menggunakan uji beda dua mean (paired t-test).

\section{HASIL DAN PEMBAHASAN}

Hasil penelitian digambarkan berdasarkan analisis univariat dan bivariat. Hasil analisis menggambarkan sampel yang diambil di SMAN 64 Jakarta Timur, sebanyak 88 responden (masingmasing 44 responden sebagai kelompok intervensi dan kelompok control). Pembahasan dilakukan melalui interpretasi dan diskusi hasil penelitian.

Tabel 1 .

Karakteristik responden berdasarkan usia penderita Fraktur Ektremitas

\begin{tabular}{llccccc}
\hline Variabel & Kelompok & $\mathrm{N}$ & Mean & Median & SD & Min-Maks \\
\hline Usia & Intervensi & 44 & 16.68 & 17.00 & 0.518 & $15--17$ \\
& Kontrol & 44 & 15.61 & 15.50 & 1.017 & $14--17$ \\
\hline
\end{tabular}

Hasil penelitian menunjukkan dan ibu tidak bekerja formal, pernah karakteristik responden di kedua menerima informasi tentang HIV dan kelompok (Tabel 1 dan 2), responden AIDS, dan tidak memiliki keluarga yang mayoritas perempuan dengan latar menderita HIV dan AIDS.

belakang pekerjaan ayah yang bekerja

Tabel 2.

Distribusi Karakteristik Responden Berdasarkan jenis kelamin, Pekerjaan Ayah, Pekerjaan Ibu, Eksposur penggetahuan, dan Anggota keluarga terjangkit HIV AIDS

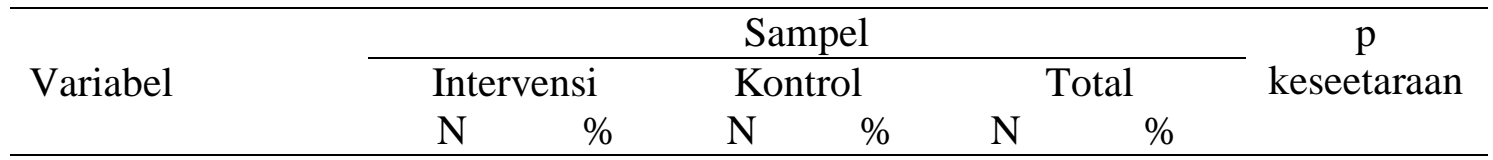




\begin{tabular}{lccccccc}
\hline Jenis Kelamin & & & & & & & 0,172 \\
$\quad$ Perempuan & 34 & 77.3 & 20 & 50 & 41 & 51.25 & \\
$\quad$ Laki-laki & 10 & 22.7 & 20 & 50 & 39 & 48.75 & \\
Pekerjaan Ibu & & & & & & & 0,124 \\
$\quad$ Bekerja & 13 & 29.5 & 12 & 27.3 & 25 & 28.41 & \\
$\quad$ Tidak bekerja & 31 & 70.5 & 32 & 72.7 & 63 & 71.59 & \\
$\begin{array}{l}\text { Pernah mendapat } \\
\text { Informasi }\end{array}$ & & & & & & & 0,174 \\
$\quad$ Ya & 44 & 100 & 44 & 100 & 88 & 100 & \\
$\quad$ Tdk & 0 & 0 & 0 & 0 & 0 & 0 & \\
Keluarga ODHA & & & & & & & \\
$\quad$ Ya & 0 & 0 & 0 & 0 & 0 & 0 & \\
$\quad$ Tidak & 44 & 100 & 44 & 100 & 88 & 100 &
\end{tabular}

Tingkat pengetahuan didalam domain kognitif mempunyai 6 tingkatan meliputi: tahu, memahami, aplikasi, analisis, sintesis, evaluasi (Fitriani, 2011). Dari hasil penelitian didapatkan karakteristik responden sebanyak 25 orang $(64,1 \%)$ mendapatkan informasi dari televisi. Responden yang mendapatkan informasi di televisi dan internet belum tentu mendapatkan informasi yang sama dengan yang di dapatkan saat mengikuti penyuluhan kesehatan. Informasi yang di dapatkan dari televisi kurang menjelaskan secara detail mengenai penyakit HIV/AIDS. Jika dibandingkan dengan informasi yang di dapatkan saat sudah mengikuti penyuluhan materinya lebih detail dan terstruktur. Oleh karena itu walaupun media massa (Televisi, Internet) memiliki pengaruh yang besar terhadap pengetahuan seseorang tetapi penyuluhan kesehatan juga sangat berperan penting dalam membangun pengetahuan seseorang. Hal ini telah terbukti dengan banyaknya penelitianpenelitian tentang pengaruh pendidikan kesehatan terhadap tingkat pengetahuan. Penyuluhan kesehatan merupakan media promosi kesehatan yang dapat mempengaruhi pengetahuan seseorang

Hasil penelitian di atas menunjukkan tidak ada perbedaan bermakna pada jenis kelamin, pekerjaan ayah, pekerjaan ibu, dan umur antara kelompok intervensi dan kelompok kontrol. Tingkat pengetahuan didalam domain kognitif mempunyai 6 tingkatan meliputi: tahu, memahami, aplikasi, analisis, sintesis, evaluasi (Fitriani, 2011). Dari hasil penelitian didapatkan karakteristik responden sebanyak 44 orang (100\%) pernah 
mendapatkan informasi tentang HIV dan AIDS, baik dari televisi, surat kabar, ataupun media social lainnya. Responden yang mendapatkan informasi di televisi dan internet belum tentu mendapatkan informasi yang sama dengan yang di dapatkan saat mengikuti penyuluhan kesehatan. Informasi yang di dapatkan dari televisi kurang menjelaskan secara detail mengenai penyakit HIV/AIDS. Jika dibandingkan dengan informasi yang di dapatkan saat sudah mengikuti penyuluhan materinya lebih detail dan terstruktur. Oleh karena itu walaupun media massa (Televisi, Internet) memiliki pengaruh yang besar terhadap pengetahuan seseorang tetapi penyuluhan kesehatan juga sangat berperan penting dalam membangun pengetahuan seseorang. Hal ini telah terbukti dengan banyaknya penelitian-penelitian tentang pengaruh pendidikan kesehatan terhadap tingkat pengetahuan. Penyuluhan kesehatan merupakan media promosi kesehatan yang dapat mempengaruhi pengetahuan seseorang.

2. Perbedaan skor pengetahuan, sikap, dan stigma sebelum dan sesudah intervensi program pendidikan kesehatan pada kelompok intervensi dan kontrol

Tabel 5.

Analisis skor pengetahuan, sikap, dan stigma sebelum dan sesudah intervensi pendidikan kesehatan

\begin{tabular}{|c|c|c|c|c|c|c|}
\hline Variabel & Kelompok & Mean & SD & $95 \% \mathrm{CI}$ & $\mathrm{T}$ & $\mathrm{p}$-value \\
\hline \multirow{8}{*}{$\begin{array}{l}\text { Skor } \\
\text { pengetahuan }\end{array}$} & Intervensi & & & \multirow{4}{*}{$-9153-1.132$} & & \multirow{4}{*}{0.123} \\
\hline & Sebelum & 62.70 & 11.623 & & -1.573 & \\
\hline & Sesudah & 66.71 & 14.406 & & & \\
\hline & Selisih & 4.01 & & & & \\
\hline & Kontrol & & & \multirow{4}{*}{$-7.464-1.314$} & & \multirow{4}{*}{0.165} \\
\hline & Sebelum & 66.04 & 17.741 & & $4 \quad 1.413$ & \\
\hline & Sesudah & 69.12 & 12.945 & & & \\
\hline & Selisih & 2.08 & & & & \\
\hline \multirow[t]{8}{*}{ Skor Sikap } & Intervensi & & & \multirow{4}{*}{$\begin{array}{l}12.572 \\
5.085\end{array}$} & \multirow{4}{*}{-4.756} & \multirow{4}{*}{$<0.001$} \\
\hline & Sebelum & 46.24 & 10.89 & & & \\
\hline & Sesudah & 55.07 & 8.77 & & & \\
\hline & Selisih & 8.83 & -2.12 & & & \\
\hline & Kontrol & & & \multirow{4}{*}{$\begin{array}{l}-8.984 \\
2.554\end{array}$} & \multirow{4}{*}{-3.619} & \multirow{4}{*}{0.001} \\
\hline & Sebelum & 46.2850 & 9.738 & & & \\
\hline & Sesudah & 52.0542 & 8.194 & & & \\
\hline & Selisih & 5.7692 & & & & \\
\hline
\end{tabular}




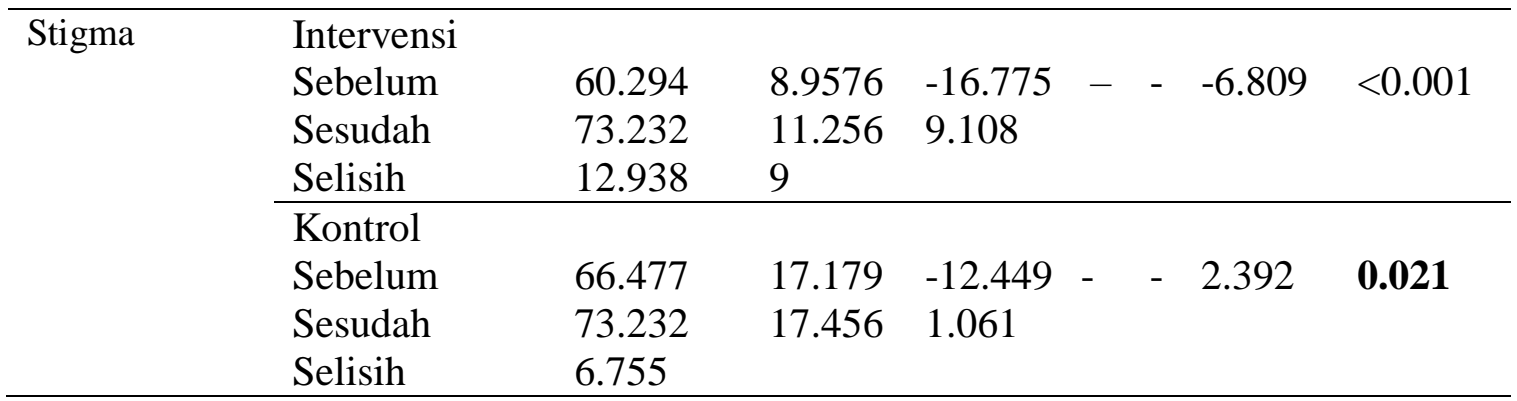

Hasil penelitian menunjukkan tidak terdapat perbedaan bermakna skor pengetahuan antara nilai sebelum dan sesudah perlakuan $(\mathrm{p}=0.123)$ pada kelompok intervensi dan $\mathrm{p}=0.165$ pada kelompok kontrol. Sedangkan variabel sikap dan stigma pada kelompok intervensi dan kontrol terdapat perbedaan bermakna sebelum dan sesudah intervensi pendidikan kesehatan (nilai $\mathrm{p}=$ $<0,001)$, dengan tiap selisih nilai rata-rata peningkatan skor sikap (nilai selisih = 4.829) dan selisih peningkatan skor stigma $($ selisih nilai $=12.94)$.

Penelitian ini sesuai dengan penelitian lain pernah dilakukan oleh Hadiningsih (2011) dengan hasil ada pengaruh positif pendidikan kesehatan terhadap pengetahuan sehingga dapat dikatakan pendidikan kesehatan dapat meningkatkan pengetahuan tentang HIV/AIDS. Selain itu penelitian Agustina, Indriyati \& Bintoro (2013) yang menyatakan terdapat pengaruh pendidikan kesehatan terhadap pengetahuan tentang HIV/AIDS pada siswa kelas XI SMUN I Teras.

Pendidikan adalah upaya persuasi atau pembelajaran kepada masyarakat agar masyarakat mau melakukan tindakantindakan (praktik) untuk memelihara (mengatasi masalah-masalah) dan meningkatkan kesehatannya. Perubahan atau tindakan pemeliharaan dan peningkatan kesehatan yang dihasilkan oleh pendidikan kesehatan ini didasarkan kepada pengetahuan dan kesadarannya melalui proses pembelajaran. Sehingga perilaku tersebut diharapkan akan berlangsung lama dan menetap, karena didasari oleh kesadaran (Notoatmodjo, 2010).

Hasil penelitian menunjukan bahwa terdapat perbedaan skor rata-rata nilai Stigma sebelum dan sesudah intervesi, sehingga dapat disimpulkan bahwa pendidikan kesehatan telah 
mempengaruhi stigma individu terhadap ODHA. Herek dan Apitiano (1999) mengungkapkan bahwa timbulnya stigma dan diskriminasi terhadap ODHA disebabkan oleh faktor resiko penyakit ini yang berkaitan dengan perilaku seksual yang menyimpang, sekse bebas, dan penyalahgunaan narkotika. Stigma dan diskriminasi terhadap ODHA dipengaruhi oleh tingkat pengetahuan dan persepsi. Hal tersebut sesuai dengan hasil penelitian yang dilakukan oleh Mahendra (2007) dan Pratikno (2008), menunjukan bahwa stigma dan ODHA oleh petugas kesehatan dipengaruhi oleh pengetahuan dan persepsi tentang HIV/AIDS. Penelitian yang dilakukan Cock (2002) menunjukan bahwa stigma dan diskriminasi terhadap ODHA berhubungan dengan rasa malu (shame) dan menyalahkan (blame) yang berhubungan dengan HIV/AIDS.

Penelitian yang dilakukan Diaz (2012) di Puerto Rico juga menyatakan bahwa adanya peran agama dalam membentuk konsep tentang sehat dan sakit serta terkait dengan adanya stigma teradap ODHA. Penelitian lain juga yang dilakukan Andrewin (2008) menyatakan bahwa terdapat hubungan antara kepatuhan beragama dengan stigma dan diskriminasi kepada penderita HIV/AIDS. Stigma dan diskriminasi yang dialami dan dilakukan anak-anak dan remaja berbeda dengan yang dialami dan dilakukan dewasa. Anak dan remaja sedang dalam proses perkembangan baik dari segi fisik, kognitif, maupun sosial. Mereka mengintrepetasikan dan bereaksi terhadap stigma dengan cara yang berbeda dari dewasa (Cree,2004).

Kurangnya informasi yang benar mengenai HIV/AIDS dan penularannya disebabkan karena dianggap bahwa membicarakan hal yang berbau sexual dianggap tabu menyebabkan adanya halangan (barrier) bagi anak muda untuk melindungi dirinya sendiri dari perilaku yang beresiko tinggi terjadinya penularan HIV (Agrawal, 2002). Pengetahuan yang kurang juga memunculkan miskonsepsi dimasyarakat, contohnya sebuah penelitian yang dilakukan pada orang yang tidak mendapatkan pendidikan di India, $45 \%$ dari partisipan menyatakan bahwa HIV dapat ditularkan melaui gigitan nyamuk (Singh, 2002). Penelitian yang dilakukan Ahwan (2012) di lakukan pada masyarakat basis anggota Nahdlatul Ulama (NU) Bangil mendapatkan hasil 
yang sama bahwa salah satu faktor pemicu tindakan stigmatisasi terhadap ODHA adalah kurangnya pengetahuan mengenai HIV/AIDS. Terdapat beberapa pemahaman yang keliru mengenai HIV/AID, seperti HIV/AIDS bisa menular melalui kontak sosial seperti bersalaman, makan bersama, menghirup udara disekitar ODHA, dan lain-lain. Pemahaman yang keliru ini menyebabkan timbulnya stigmatisasi terhadap ODHA.

Menurut penelitian Ahwan (2012) salah satu faktor penyebabnya adanya stigmatisasi terhadap ODHA adalah pandangan agama. Agama memiliki pengaruh yang kua terhadap cara pandang dan pola perilaku manusia, atas nama agama bisa dijadikan sebagai justifikasi dan kegitimasi untuk memberikan sikap dan tindakannya, salah satunya stigmatisasi. Padahal agama tidak mengajarkan tindakan stigmatisasi dalam hal apapun, justru agama mengajarkan tentang nilai-nilai kasih sayang kepada sesama manusia.

\section{SIMPULAN}

Penelitian menghasilkan terdapat perbedaan secara bermakna rata-rata skor stigma kelompok intervensi antara sebelum dan sesudah pemberian pendidikan kesehatan tentang HIV dan AIDS. Sedangkan dalam uji korelasi, terdapa hubungan signifikan antara pengetahuan dengan stigma. Berdasarkan hasil tersebut, maka perlu diberikan pendidikan kesehatan tentang HIV dan AIDS secara terus menerus dan dijadikan agenda rutin pendidikan kesehatan terhadap seluruh pelajar dimanapun berada.

\section{UCAPAN TERIMA KASIH}

Ucapan terima kasih terutama ditujukan kepada pimpinan dan jajaran, serta pelajar SMAN 64 yang telah berpartisipasi sebagai responden dalam penelitian ini.

\section{DAFTAR RUJUKAN}

Aggleton, P., Parker R., \& Maluwa M. (2003). Stigma, Discrimination and HIV/AIDS in Latin America and the Caribbean. Washington, DC: InterAmerican Development Bank.

CRPD. (2007). Convention on the Rights of Persons with Disabilities: Article 2 ohchr.org. 
Elliott, J. (2005). Using narratives in social research: Qualitative and quantitative approaches. London: Sage.

Giddens, A., Duneier, M., Appelbaum, R.P., \& Carr, D. (2009). Introduction to Sociology. 7th ed. New York. w.w. Norton \& Company, Inc.

Goffman, E. (1963). Stigma: Notes on Management of Spoiled Identity. Englewood Cliffs, NJ: Prentice Hall. Haeriyanto, S.(2016). Analisis Faktor Yang berhubungan dengan Stigma terhadap ODHA (Studi pada emaja di Jakata Timur).

Poltekkes Kemenkes Jakarta III, Bekasi.

Heatherton, et al. (2000). The Social Psychology of Stigma. New York: Guilford Press.

ICAD. (2012). Fueling the Epidemic: HIV-Related Stigma and Discrimination (Publication. Retrieved 15 February 2015, from Interagency Coalition on AIDS and Development ICAD):http://www.icadcisd.com/pdf
/FuelingtheEpidemicHIVRelatedSti gmaandDiscriminationInfoSheetEN. pdf

Jacoby, A. (2005 ). Epilepsy and Social Identity: the Stigma of a Chronic Neurological Disorder. The Lancet Neurology 4(3), 171-178.

Kohi,T.W., Makoae, L., Chirwa, M., Holzemer, W.L., Phetlhu, D.R., Uys, L., Naidoo, J.,Dlamini, P.S. \& Greeff, M. (2006). HIV and AIDS Stigma Violates Human Rights in FIVE African Countries. Nursing Ethics, 13 (4): p. 405-415.

Krisanty, P., Sumartini, M., Wartonah (2014). Stigma Terkait HIV: Persepsi dan Sikap Mahasiswa Perawat Terhadap Pasien HIV. Poltekkes Kemenkes Jakarta III, Bekasi.

Krisanty, P., Ekarini, LP., Haeriyanto,S. (2015) Studi tentang Stigma pada Mahasiswa Perawat. Poltekkes Kemenkes Jakarta III

Madumo, M.M., \& Peu, M.D. (2006). The views of Undergraduate Nursing Students on Caring for Patients with 
HIV/AIDS (Publication. Retrieved 17 May 2015, from http://curationis.org.za/index.php/cu rationis/article/viewFile/1109/1044. pdf

Major, B., \& O'Brien, L. T. (2005). Stigma Sociological Theory. Annual Review of Psychology, Vol.56 (1), 393-421.

Paryati, T., et al. (2012). Faktor-faktor yang Mempengaruhi Stigma dan Diskriminasi kepada ODHA(Orang dengan HIV/AIDS) oleh petugas kesehatan : kajian literatur (Publication. Retrieved 19 February 2015, from Pustaka Universitas Padjadjaran:

http://pustaka.unpad.ac.id/wpcontent/uploads/2013/02/Pustaka_u npad_Faktor_-Mempengaruhi_Stigma_ODHApdf.pd

Sastroasmoro, S., \& Ismael, S. (2010). Dasar-dasar Metodologi Klinis, Edisi ke-4. Jakarta: Sagung Seto.
Thomas, M. P. (2009). Stigma and Discrimination: Investigating Final Year Student Nurses Attitudes and Perceptions of People Living With HIV in Guyana. The University of the West Indies, St. Augustine.

UNAIDS. (2014). Fact Sheet 2014 (Publication. Retrieved 10 February 2015, from UNAIDS: http://www.unaids.org/sites/default/f iles/en/media/unaids/contentassets/d ocuments/factsheet/2014/20140716_ FactSheet_en.pdf

Waluyo, A. (2011). Indonesian Nurses' HIV Knowledge, Religiosity, Individual Stigma Attitudes, and Workplace HIV-Stigma (Publication. Retrieved 25 February 2015, from College of Nursing University of Illinois at Chicago: http://indigo.uic.edu/bitstream/handl e/10027/8045/waluyo_agung.pdf?se quence $=1$ 